\title{
What Decides the Exchange Rate? Theory - and Predictions of the Norwegian Krone against the Euro
}

\author{
Per Halvor Vale \\ Norwegian University of Life Sciences, \\ School of Economics and Business
}

\begin{abstract}
The paper analyses changes in the exchange rate of the Norwegian krone (NOK) as measured against the Euro, with the purpose of forecasting future exchange rates. The analysis is based on an error correction model. The model is given an autoregressive form. From the model is derived "out-of-sample forecast". The predictions are compared with forecasts obtained from a Random Walk model. The empirical findings show that even though the economic model identifies several important explanatory variables, the Random Walk model performs better.
\end{abstract}

Kewords: Exchange rate, equilibrium exchange rate, out-of-sample forecasts JEL classification: C22C32, C53, F31

\section{INTRODUCTION}

It is important for decision-makers in economic sector to have a clear idea as to the causes of fluctuations in the exchange rate. This paper analyses variations and shifts in the exchange rate of the Norwegian currency measured against the euro. The purpose is to understand the driving forces and make predictions about likely changes in future exchange rates. To test the viability of the model we blank out some of the sample data and make "out-of-sample forecasts". The forecast model is challenged by a Random Walk model (RW).

Figure 1.1 illustrates the development in value of the NOK as against the Euro in the period 2001-2018. The range exceeds 30 per cent, while changes in the preceding observations and trends might be abrupt. All of this is likely to pose significant challenges for actors involved in the exchange rate market and international business (and for the researcher).

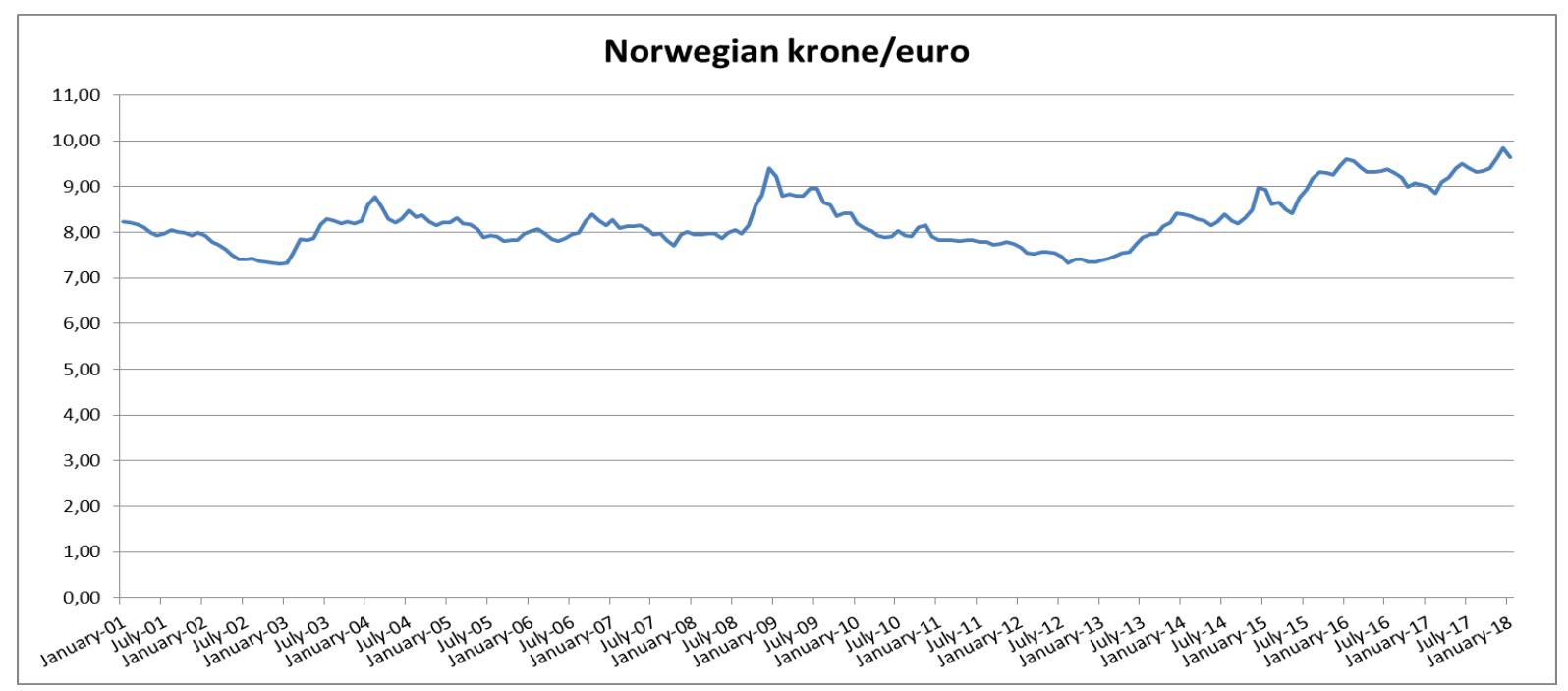

Figure 1.1: The value of the NOK as against the Euro in the period 2001-2018 
The rest of the article is organized as follows: Chapter 2; literature review, chapter 3; the model, chapter 4; data specification, chapter 5; econometrics comments, chapter 6; empirical findings, chapter 7; prognoses - "out-of-sample forecasts"; chapter 8; summary.

\section{The long line}

\section{LITERATURE REVIEW}

When the Bretton Wood agreement broke down in the 1970's and a number of currencies were allowed to float, the flexible monetary model by Frenkel (1976) became an indispensable workhorse for exchange rate studies. The model assumed that prices, including the price of a currency, were perfectly flexible, that domestic and foreign assets were perfectly substitutable and that the Purchase Power Parity hypothesis - PPP-hypothesis - held good. After the subsequent liberation of the capital across the countries in the 1980's, a further hypothesis could be added - that of uncovered interest rate parity.

The wide fluctuations in exchange rates after Bretton Woods came as a surprise to many economists (Blanchard, 2000). Most economists held the view that ideal markets would force exchange rates to approach equilibrium - and to remain there. From this perspective - volatility in the exchange market - could only be a consequence of misplaced interference in the operation of the market. Frankel and Jeffry (1979), however, distinguished between long-term equilibrium, which coincided with the approach of equilibrium in flexible monetary models, but in the short run the spot exchange rate deviated due to price rigidity. The paper introduced Dornbusch (1986), arguing that the foreign exchange market would overreact to any changes in monetary policy or other events, before arriving at a new short-run equilibrium. In time, however, the prices of goods would undergo change and the foreign exchange market tends towards less overreaction, allowing the exchange rate to move towards a lasting equilibrium.

The exchange rate literature today also presents microstructure approaches, with the focus on the actors in the exchange rate market and their expectations of future exchange rates.

\section{Ability to predict.}

Meese and Rogoff (1983) compared the accuracy of exchange rate projections based on classical economic models, first of all the PPP hypothesis and uncovered interest rate parity, with the RW model. They found that forecasts of exchange rates relying on economic fundamentals could not outperform a RW based forecast. This was a devastating critique of the standard economic models.

Significant contributions for a better understanding of exchange rate variations were new multivariate time series models, inter alia so-called error correction models, in the 1990's. Bjørnland and Hungnes (2003) applying this new technic on Norwegian data demonstrated that economic theory could beat the RW-model. However, other studies, also using Norwegian data, cast doubt on this conclusion, see for example Adrik (2016).

This disagreement is the motivation for taking a closer look at the choice of models for predicting variations over time in the exchange rate. More papers / projects varying in specification of models and variables hopefully accumulate knowledge and may contribute towards a clarification of models / variables for making good predictions.

\section{The profile of the paper}

The paper benefits from an autoregressive model form. The period studied is 2001 to 2016, when Norway practiced a floating exchange rate regime. Throughout this period, the 
petroleum sector was dominant in the Norwegian economy. Hence, oil prices in addition to data for the Norwegian Petroleum Fund are incorporated as explanatory variables. The prognoses are based on the "out-of-sample forecasts" technique. A random walk model challenges the forecasts obtained.

An important basis for these choices is a review of earliere studies of Norwegian krone: Reiton and Ongena (1999), Eitrheim et al. (1999), Akram (2002) and (2003), Bernhardsen and Røisland (2000), Naug (2003), Kloster et al. (2003), Bjørnland and Hungnes (2003) and (2006), Bjørnstad and Jansen (2006) and (2007). Aamodt (2009), , Kj (2015), Papadimitriou et al. (2007), Flatner (2009), Gimmingsrud (2012) and Adrik (2016).

\section{Time union}

\section{THE MODEL}

The model applies monthly data. These data will smooth out some of the daily variations, which would be difficult to encompass in the model. Still, it is a large number of observations,

It is plausible that the effect of an independent variable - such as rate of interest, and cyclical indices - is not exhausted in the course of a month, and that the same variable therefore can be assumed to be active even in subsequent observations of the exchange rate. That means that the spot exchange rate at time $t$, would be a function of lagged exchange variables observed at time $\mathrm{t}-1, \mathrm{t}-2$, etc, and that an autoregressive model would be called for.

\section{Independent variables}

The relevance of most of the right-hand side variables specified in equation (1) are demonstrated in the literature mention in section 2.3, for example the lagged value of the exchange rate, oil prices, interest rates difference, Oslo Stock Exchange and anxiety concerning global financial markets. When Norwegian krone / US-dollar is specified the hypothesis is that the actors in the exchange market want to utilize the arbitrary possibilities in the triangular currency market of the dollar, the euro and the krone. The argument for the inclusion of the Petro Fund rests on the hypothesis that as large a fund lends confidence to the stability of the currency's rate of exchange, with the further suggestion that the krone might prove as a safe haven in bad times.

The term in brackets in equation (1) represents the divergence between the current exchange rate and the equilibrium. Under free trade and free movement of capital, it would be reasonable to expect a convergence of commodity prices, regardless of habitation. In other words, in the end we should expect the requirement for the PPP to be fulfilled. The error correction term also allows the long-term equilibrium currency to be dependent on other variables, for example the uncovered interest rate hypothesis, the price of oil and the size of Petro Fund.

The $\theta_{1}$-parameter, governing the error correction term, indicates the time required for the market mechanism to eliminate the gap between the current and the equilibrium rates of exchange.

Note that the variables are in log form (except for the variation in interest rates). The variables in growth form thus represent percentage changes, while the model's parameters then show the percentage changes in the current exchange rate per percentage changes in the right-hand side variable.

The dummy variables are reflecting the exceptional economic/political situation arising during 
the financial crises, and in the subsequent bank crisis and in the euro-zone.

$$
\begin{aligned}
& \Delta \text { NokEuro }_{\mathrm{t}}=\mathrm{a}+\sum_{i=1}^{n} b_{\mathrm{i}} \Delta \text { NokEuro }_{\mathrm{t}-1}+\sum_{i=1}^{n} c_{\mathrm{i}} \Delta\left(\mathrm{i}-\mathrm{i}^{*}\right)_{\mathrm{t}-1}+ \\
& \sum_{i=1}^{n} d_{\mathrm{i}} \Delta \text { oil price }_{\mathrm{t}-1}+\sum_{i=1}^{n} e_{\mathrm{i}} \Delta \text { NokUSd }_{\mathrm{t}-1}+\sum_{i=1}^{n} g_{\mathrm{i}} \Delta \mathrm{VIX}_{\mathrm{t}-1}+ \\
& \sum_{i=1}^{n} f_{\mathrm{i}} \Delta \text { OSBX }_{\mathrm{t}-1}+\sum_{i=1}^{n} h_{\mathrm{i}} \Delta \text { Petrofund } \mathrm{t}-1+ \\
& \theta_{1}\left[\text { NokEuro }-\left\{\left(\mathrm{p}^{\mathrm{N}}-\mathrm{p}^{\mathrm{E}}\right)_{\mathrm{t}}+\theta_{2}\left(\mathrm{i}-\mathrm{i}^{*}\right)_{\mathrm{t}}+\theta_{3} \text { oil price } \mathrm{t}-1++\right.\right. \\
& \left.\left.\theta_{4} \text { NokUSd }_{\mathrm{t}-1}+\theta_{5} \mathrm{VIX}_{\mathrm{t}-1}+\theta_{6} \text { OSBX }_{\mathrm{t}}+\theta_{7} \text { Petrofund }_{\mathrm{t}-1}\right\}\right]+\varepsilon_{\mathrm{t}}
\end{aligned}
$$

where

$\mathrm{n}=3$ and $\mathrm{k}=2$

- NokEuro $\mathrm{t}_{t}$ is the logarithm of the exchange rate for the Norwegian krone to the euro at time $\mathrm{t}$

- Oil price $t$ is the logarithm of burning oil price at time $t$

- $\left(i-i^{*}\right)_{t}$ is the difference between three-month interest rates in respectively Norway and the Euro-zone at time $t$

- NokUSd $d_{t}$ is the log of the exchange rate for the Norwegian krone to US dollars at time $t$

- $\left(\mathrm{p}^{\mathrm{N}}-\mathrm{p}^{\mathrm{E}}\right)_{\mathrm{t}}$ is the log of the difference between the consumption price level in Norway and the Euro-zone at time $t$

- $\mathrm{OSBX}_{\mathrm{t}}$ is the log of the total index of the Oslo Stock Exchange

- PetroFund $\mathrm{t}_{\mathrm{t}}$ is the log of the market value of the The Government Pension Fund Global

- VIX $\mathrm{V}_{\mathrm{t}}$ is the log of an index for international financial turbulence (VIX-index)

- $\mathrm{D}_{1}$ is the dummy variable for the Finance crisis, and is set at 1 for the months from 2008:1 to 2009: 4, otherwise zero

- $\mathrm{D}_{2}$ is the dummy variable for the bank crisis in the Euro-zone, and is set at 1 for the months 2011:2 to 2013: 3, otherwise zero.

\section{Equilibrium exchange rate}

An expression for the long-term equilibrium exchange rate is obtained by putting all growth form variables in equation (1) equal to zero. This gives equation (2), which implies that the short term exchange rate might deviate from the equilibrium rate.

Equation (2) further shows that the long-term equilibrium exchange rate depends on the PPP hypothesis $\left(\mathrm{p}_{\mathrm{t}}^{\mathrm{N}}-\mathrm{p}_{\mathrm{t}}^{\mathrm{E}}\right)$ and could depend as well on uncovered interest rate pariti, the price of oil, the size of Petro Fund, the instability of the global economy and the US-dollar.

$$
\begin{aligned}
& \text { NokEurot }_{t}=\left(\mathrm{p}^{\mathrm{N}}-\mathrm{p}^{\mathrm{E}}\right)_{\mathrm{t}}+\theta_{2}\left(\mathrm{i}-\mathrm{i}^{*}\right)_{\mathrm{t}}+\theta_{3} \text { Oil price } \\
& \Theta_{5} \text { VIX }_{\mathrm{t}}+\theta_{6} \text { Petrofund }_{\mathrm{t}}+\theta_{7} \text { OSBX }_{\mathrm{t}}+
\end{aligned}
$$

\section{Out-of-sample forecasts}

To perform out-of-sample forecasts, some sample data are blocked out. The data identifying the model and estimating the parameters are from the period 2001:1 - 2011:1. From this estimated model, forecasts are made for the period 2011:2 - 2017:4.

The paper constructs prognoses with different time horizons. For more details, see chapter 6 . 


\section{DATA SPECIFICATION}

As said, the data cover monthly data from 2001:1 to 2017:4. The variables are derived from the sources given below.

The variables in the model are in log form, where changes in value measure percentage variations in the variables.

- The price level is represented by the consumer price index.

- The interest rate level is represented by three-monthly money market interest rates.

- The price level of oil is represented by the price of Brent blend crude.

- The Fund is represented by the market value of the fund in Norwegian krone.

- NokEurot; source - monthly exchange rates from Norges Bank

- Oil-price $t-1$, source - monthly Brent blend index

- $i_{t}$, source - three month rates in Norway and the Euro-zone

- $i^{*}$ t, source - three month rates in euro-arena

- NokUSd $_{\mathrm{t}}$, source - monthly exchange rates from Norges Bank

- OSEBX $_{t}$, source - total index of the Oslo Stock Exchange

- VIX $_{t}$, source - the Chicago Board Options Exchange

- $\quad \mathrm{p}^{\mathrm{N}}{ }_{\mathrm{t}}$, source. Norwegian consumer prices

- $\mathrm{p}_{\mathrm{t}}^{\mathrm{E}}$, source - Euro statistics, consumer prices

- PetroFund,t, source - Norges Bank

- D1 is a dummy variable for financial crises, and is set at 1 for 2008:3 to 2009:4, otherwise 0 .

- D2 is a dummy variable for the bank crises in the Euro-zone, and is set at 1 for 2011: 2 to 2013:4, otherwise 0 .

\section{ECONOMETRY}

Ordinary Least Square Method (OLS) estimates are shown in Table 5.1. This result is based on the complete sample of 175 observations.

The OLS requires that many underlying assumptions are met. Macro variables on level form are often not stationary and an important source of spurious estimates. Many of the macro variables in the model are in growth form, and one should expect them to be stationary. This was also confirmed by an Augmented Dickey-Fuller test, see Appendix 1: Diagnostic tests.

In contrast, the error correction term comprises variables on level form. An equation with a mix of growth and level variables represents a statistical econometric challenge. The primary way out of such a conundrum is to test for co - integration. We therefore conducted a regression analysis of level variables and tested the residue for a unit root, i.e. 1(0). The empirical finding showed that co-integration was present, which made it possible to apply LES.

Appendix 1 also shows other diagnostic tests, derived from the PC-give test program. The results show, inter alia:

- All variables on growth form become stationary.

- The hypotheses of normal distribution of the residuals cannot be rejected.

- We cannot reject the hypotheses of homoscedastic.

- We must reject autocorrelation - and it is no correlation of the residuals over time.

- Neither represent strong multi-correlation any problem. 


\section{Impact of independent variables}

\section{EMPIRICAL RESULTS}

Table 6.1 exhibits the empirical results after having simplified the model by eliminating variables that are not significant.

Col.2 shows the parameters estimated for the variables in the final model, col.3 demonstrates the T-value in a test to determine the significance of variation from zero, and col.4 exhibits the likelihood level in a test if the parameter significantly different from zero.

In chapter 2.3, we listed earlier studies of the Norwegian currency. Notice that these studies occurred spread out in time, and therefore deviate from one another and this study - with respect to data, currency regime, model approach and model specification etc. However, when we tried to correct for such differences, we found that the results in table 6.1 are in reasonably good agreement with the findings of the earlier research.

Tabell 6.1: Estimating of equation (2)

\begin{tabular}{|c|c|c|c|}
\hline Parameter & Estimate & T-value & P-value \\
\hline$\Delta$ Nok/Euro t-1 & 0.21 & 2.77 & 0.007 \\
\hline$\Delta\left(\mathrm{i}^{\mathrm{N}}-\mathrm{i}^{\mathrm{E}}\right) \mathrm{t}-2$ & -0.35 & -2.90 & 0,005 \\
\hline$\Delta$ Oil price $\mathrm{t}-1$ & -0.01 & $-0,88$ & 0.38 \\
\hline$\Delta \mathrm{VIC}$ & $-0,01$ & $-1,93$ & 0,056 \\
\hline$\triangle \mathrm{OSEBX}$ & 0.03 & 1.60 & 0.11 \\
\hline$v\left(\right.$ NokEuro $\left.-\left(p^{N_{t}}-p_{t}^{E}\right) \ldots ..\right)$ & -0.06 & -2.55 & 0.012 \\
\hline$\left(i^{N}-i^{E}\right) t-1$ & $-0,11$ & $-1,67$ & 0,096 \\
\hline Petro Fund & 0.004 & 2,55 & 0.012 \\
\hline $\begin{array}{l}\text { Dummy variable D2; Bank } \\
\text { crises in EU-area }\end{array}$ & $-0,004$ & $-2,04$ & 0,04 \\
\hline
\end{tabular}

\section{Effects on the exchange rate in the short term}

- The most recently observed change in the exchange rate will exert a significant influence on the likely next observation. Should the exchange rate dip by 1 percent at time $t-1$, table 6.1 shows that the exchange rate depreciate by 0,21 percent at time $t$. The explanation of this effect might be herd mentality, i.e. that actors in the foreign exchange market might rely on observed occurrences as heralding trends in the developments of the exchange rate in question, (Rime and Sjoli, 2003) and Naug (2004)

- Changes in the gap between interest rates in Norway and in the Euro-zone have an impact on the exchange rate. If a gap between Norwegian and Euro-zone should increase, due to a rise in favor of Norwegian, the krone would be likely to appreciate in the short-term foreign exchange market. The interest spread is not log in form and this must be taken into account when specifying the relationship between changes in Norwegian interest rates and percentage changes in the exchange rate. Assume that the Norwegian interest rate rises from 3.0 to 3.5 percent (equal to a 17 per cent rise) while the interest rate in the Euro-zone remains at 3.0 percent. The result would then be a change in the exchange rate of $100 \times 0.31 \times 0.5=15.5$ percent, while Norwegian interest rates had appreciated by 15.5 percent. Compared to a one percentage point rise in interest rates, the rate of exchange of the krone to the Euro would have appreciated by 0.91 percent, i.e. an elasticity of - 0,91 .

- Table 6.1 shows that the elasticity of the exchange rate with reference to the price of oil is insignificant. The reason why some would expect a positive correlation between oil prices and exchange rate, is that the higher oil price, the greater the demand would be 
for Norwegian kroner (ceteris paribus). On the other hand, much of this effect is neutralized when oil revenues are deposited in The Fund. It is thus not obvious that oil prices play any significant part when the exchange rate gets fixed.

Possible indirect effects of a rise in oil prices concern the financial strength of the Norwegian petroleum sector, and the possibility that the Norwegian currency might be regarded as a safe haven in uncertain times. This question is touched in next bullet point and in in later section 6.3: Long-term equilibrium.

- Table 6.1 shows that the index of turmoil in the global economy (the WIC index) is narrowly negative. This means that the more unstable the global economy (within the limits of data sets), the stronger is the Norwegian currency. This result might imply that when there is turmoil in financial and currency markets, the Norwegian currency has been regarded as a safe haven by players in the foreign exchange markets. It may be likely that this was the case during the bank crisis in the euro-zone in the years 20112012. However, as a universally conclusion, this result would be unexpected.

- The parameter for the total index of the Oslo Stock Exchange (OSEBY) is not significant. Naug (2003) castes light over this result when he writes: "it might be mentioned that the bond market is often regarded as attractive for investors looking for alternatives to a volatile stock market - even when a rise in the stock index takes place"

- Table 6.1 shows a strengthening of the currency in the period 2011-2013, i.e. during the bank crisis in the Euro-zone. The explanation for this might merely be the same as mentioned in a bullet point above, viz that the krone was perceived as a safe haven for those with holdings of a volatile Euro.

\section{Long-run equilibrium value}

The estimate of the coefficient governing the error term is negative and significant. The parameter reflects the currency's returns back to equilibrium. The parameter was estimated at approximately 0.06 , which means that the divergence between the current exchange rate and the long term equilibrium is corrected monthly by 6 percent, such that equilibrium is reached within a span of 16-17 months.

The originally model imposes that the exchange rate stands in one - to - one relationship to the relative price relationship between Norway and Euro-zone, reflecting the purchase power hypotheses. Long run equilibrium exchange rate will in addition change by permanent changes in some key variables. The results in table 6.1 show that Norwegian krone will increase if the interest rate gap permanently increases in favor of the rate in Norway. Also permanently higher Petro Fund will make the Norwegian krone stronger.

If the estimates in table 6.1 is put into equation (2), omitting non-significant estimates, equation (3) is obtained.

(3 NokEuro $_{t}=\left(\mathrm{P}^{\mathrm{N}}-\mathrm{P}^{\mathrm{E}}\right)_{\mathrm{t}}-0.11\left(\mathrm{i}-\mathrm{i}^{*}\right)_{\mathrm{t}}-0,004$ Petrofund $+\varepsilon_{\mathrm{t}}$

Figure 6.1 exhibits the curve for monthly observations of the exchange rate for the krone to the Euro, together with computed long-term equilibrium rates. The long-term curve is relatively flat. In contrast, the spot curve shows relatively severe oscillations. During the financial crisis in 2008-09 the krone depreciated, while it appreciated under the bank crisis in the euro area in 2011-2012. From 2014 - and when it come a large cut in the oil price - the krone's exchange rate depreciate and exceeds the equilibrium rate and generates an increasing gap between the short and long-run rates. 


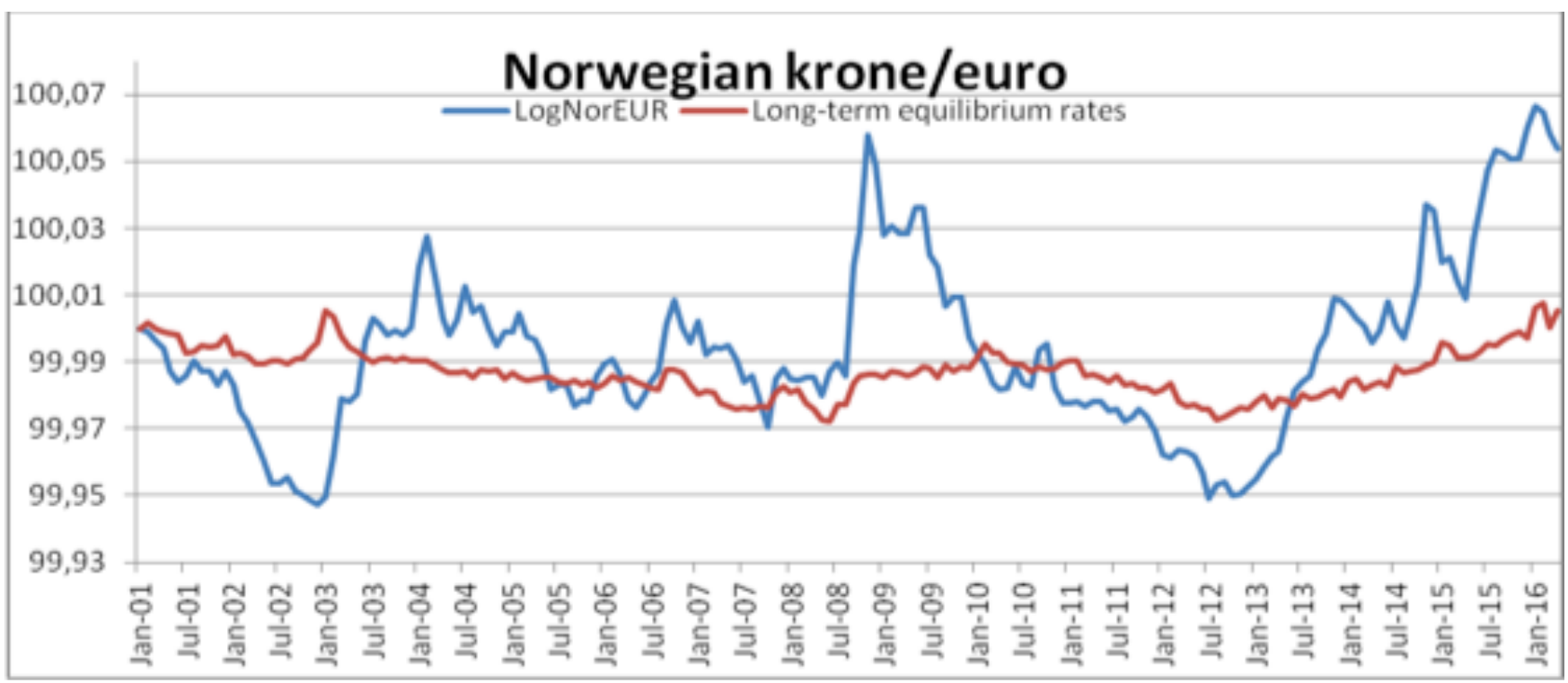

Figure 6.1: Monthly observations of the exchange rate for the krone to the Euro, together with computed long-term equilibrium rates. January $2008=100$.

\section{PROGNOSES. OUT-OF-SAMPLE FORECAST}

With "out-of-sample" forecasts, it is possible to compare predictions to observed spot exchange rates. The gap between the predictions and the observed exchange rate can be a measure of the model's fit. The less the gap, the better the model.

As a measure of the gap is applied Root Mean Square Error (RMSE), see equation (4) below, where the term marked with an asterisk * is the predicted change in the exchange rate at time $t$, while the initial term in the equation is the observed change. An alternative measure is the Mean Average Error (MAE), see equation (5).

$$
\begin{aligned}
& \text { RMSE }=\sqrt{1 / \mathrm{n} \sum_{t=1}^{n}(\Delta \text { NokEurot }-\Delta \text { NokEuro } \mathrm{t})^{2}} \\
& \mathrm{MAE}=1 / n \sum_{t=1}^{n}(\Delta \text { NokEuro } \mathrm{t}-\Delta \text { NokEuro } \mathrm{t})^{2}
\end{aligned}
$$

An additional criterion to evaluate the goodness of the forecasts of the model is whether the forecast would anticipate changes - upward, level or downward - in an observed trend

Notice, we must also control the goodness of the forecast model, which require alternative forecast models (not only different evaluation criterion). As benchmark model, we have applied the random walk model. The reason for using a simple and naïve RW - model as reference, is due to the fact that since Meese and Rogoff's (1983) papers, many studies have shown the RW-model to be superior to models based on fundamental economic variables.

The paper also make allowance for models having different properties with regard to making either short term or long-term predictions. The paper therefor calculates 1-step forecast for periods of respectively 6,24 and 50 months.

Figure 7.1 exhibits 1-step forecasts for the exchange rate when the horizon of the forecasts is 50 months. For the first 20 months, the predictions are good. In month 133/134, the gap between the forecasts and the observed exchange rate widens, which coincides with autumn 2012 when the Euro Central Bank, the ECB, calmed the financial markets by announcing free unlimited support for all Euro-zone countries involved in a sovereign state bailout program. 
Thereafter the euro normalized - after a period of being re-garded as uncertain - while the Norwegian krone depreciated.

The second, and more pronounced gap, occurred at month 163. It coincided with the unexpected autumn 2014 collapse of the price of petroleum. Shortly afterwards the forecast again coincides with the current rate. This suggests that the markets had anticipated a speedy return to a normalization of the rates (and the price of oil). However, subsequently forecasts have consistently over-estimated the exchange rate and shown values far below the observed rates.

Figure 7.2 shows forecasts of the exchange rate based on the RW model. The gap observed between the forecasts the actual exchange rate is pronounced in the same months as produced by the error correction model, viz. month 132 and 163.

The results obtained in figure 7.1 and 7.2 do not permit any conclusion to be drawn as to the model most suited for predicting changes in the exchange rate. We therefor exhibit table. 7.1 showing the more detailed measures obtained by means of the equation 5.1 and 5.2.

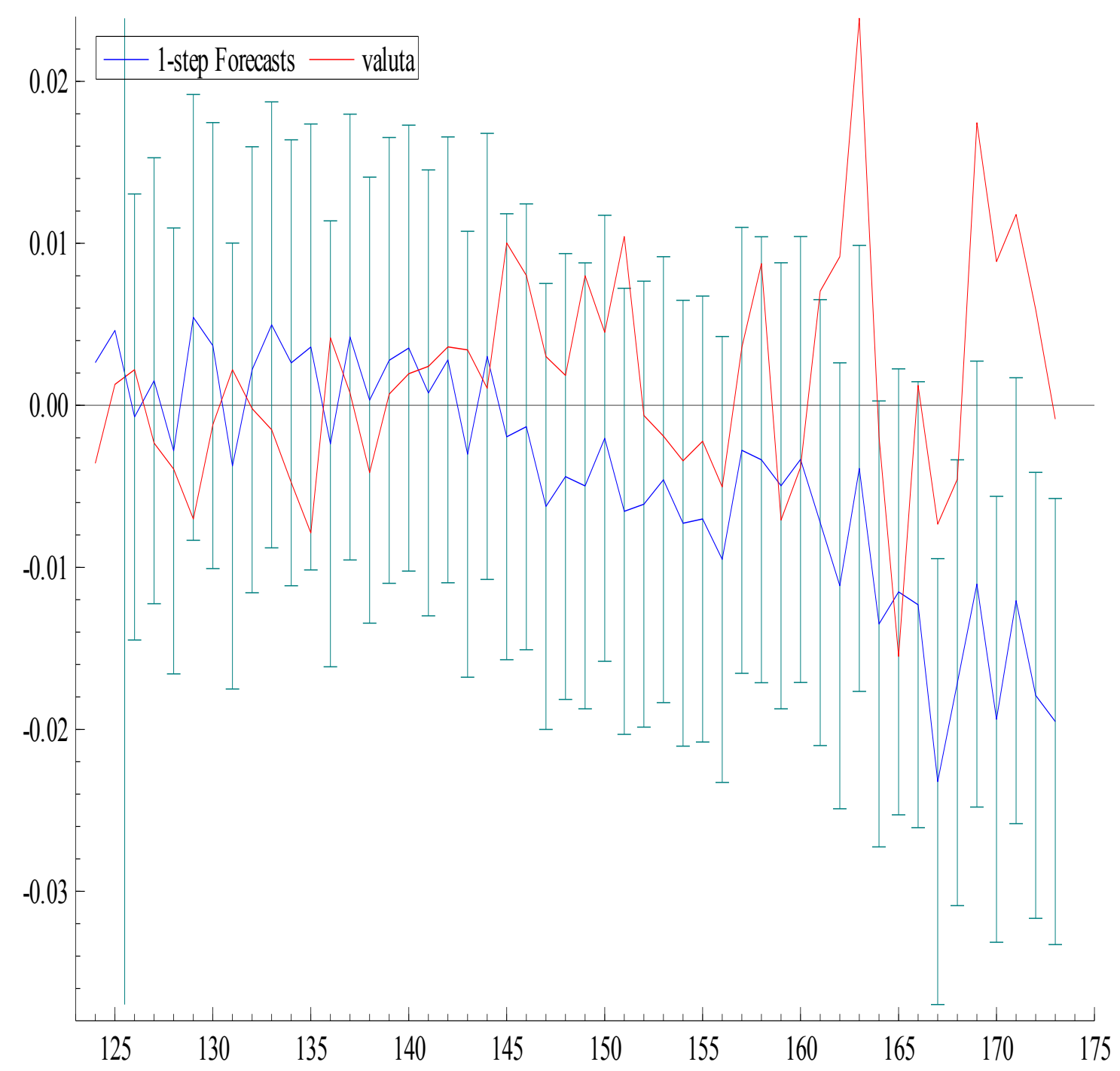

Fig 7.1 Exchange rate 1-step forecasts for a horizon of 50 months based on the error correction model in equation (1). 


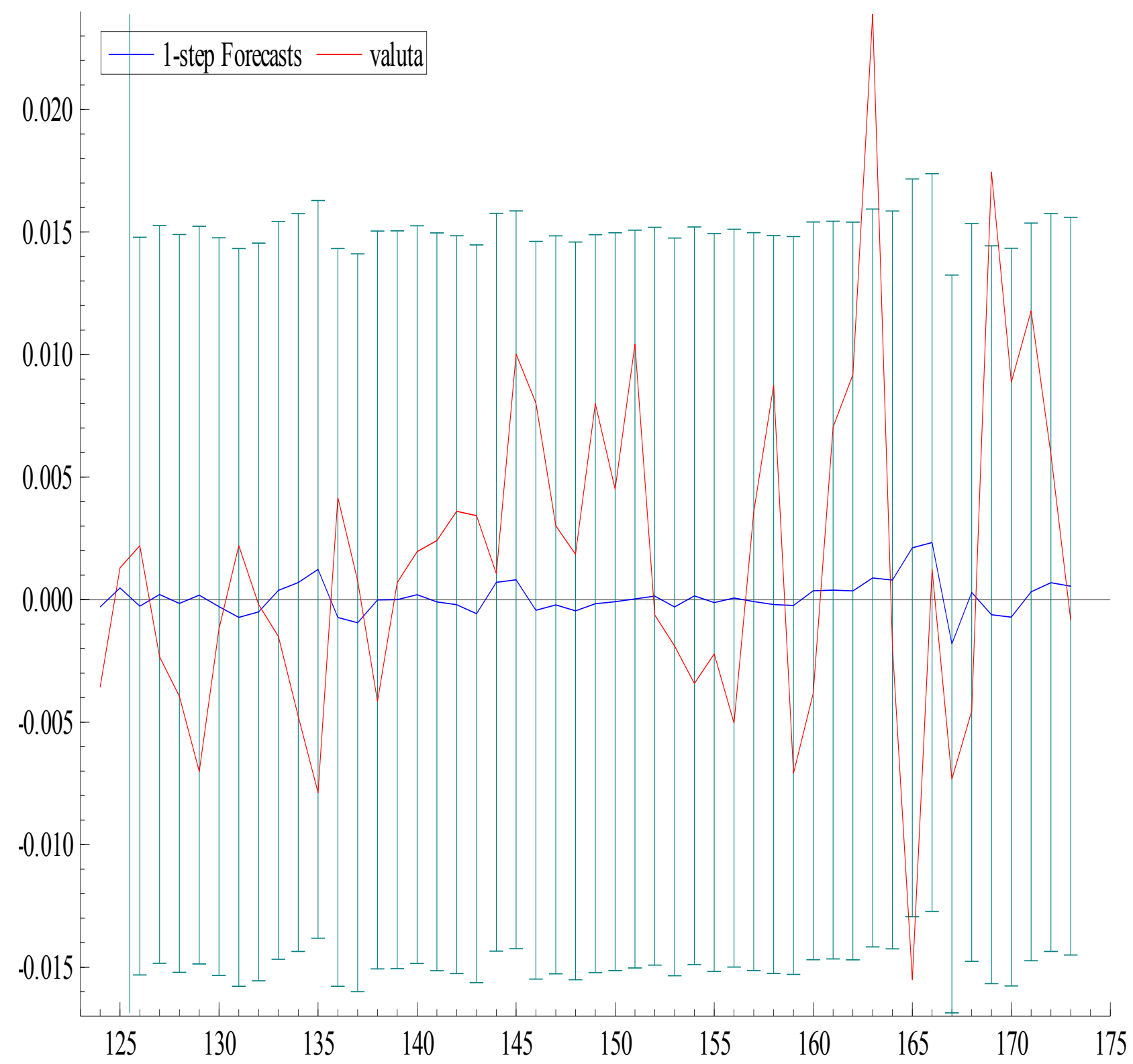

Fig 7.2 Observed and predicted rates based on RW model

It is not possible from figure 7.1 and figure 7.2 to decide which model explains developments in the exchange rate best during the valuation period. We then resort to the mathematic criteria RMSE and MAT in table 7.1. The smaller the numbers in the table's cells are, the better the fit of the forecasts. The table proves the RW model to be superior to the economic model applying the RMSE and MAPE criterion for all alternatives of horizon, both in the short and in the long run. 
Table 7.1: RMSE and MAT computations for 1-month forecasts with horizons of 6 months, 24 months and 50 months.

\begin{tabular}{|l|c|l|l|l|l|l|}
\hline \multirow{2}{*}{ Model } & \multicolumn{5}{|c|}{ Horizon } \\
\cline { 2 - 7 } & 4 months & \multicolumn{2}{c|}{12 months } & \multicolumn{2}{c|}{25 months } \\
\cline { 2 - 7 } & RMSE & MAPE & RMSE & MAPE & RMSE & MAPE \\
\hline $\begin{array}{l}\text { Error } \\
\text { Corretion- Model }\end{array}$ & 0,0055 & 416,6 & 0,0058 & 461,8 & 0,0055 & 315,8 \\
\hline \multirow{2}{*}{ Random walk } & 0,00234 & 168,4 & 0,0029651 & 127.40 & 0,00386 & 109,6 \\
\hline
\end{tabular}

With respect of whether the forecast would anticipate the next variations (upward, level or downward) in the observed trend, the error-correction model proved to be superior, with 20 out of 50 hits, while the Random Walk model had a score of only 7 correct anticipations.

\section{SUMMARY}

The empirical analysis of the error correction model identifies several factors with an effect on the Norwegian currency against the euro.

- Observed changes in the exchange rate at time $t-1$ have a significant effect on the exchange rate at time $t$.

- A rise in interest rates in Norway, relative to the interest rate in the euro-area, would strengthen the exchange rate.

- The study confirms the persistence of the PPP hypothesis as well as the uncovered interest rate parity.

- The forces in the exchange rate market try to achieve a closing of a gap between current and equilibrium rates, and all other things the same, succeed after some time.

Even so, the model does not prove superior to a RW model in making exchange rate forecasts. Applying the RMSE and MAPE criteria, RW even make best, independently of the horizon of forecasts $(4,12$ and 24 months).

With respect of whether the forecast would anticipate the next changes in the observed trend, the error-correction model make best - and had 20 (of 50) correct anticipations while Random Walk model had 7 correct anticipations.

\section{References}

Aamodt, E. (2009). Valutakursmodellering av den norske valutakursen, en undersøkelse av informasjonsinnholdeti Nkr / Skr. Masteroppgave i samfunnsøkonomi, NHH, 2009.

Adrik, S (2016). Evaluating Benchmarks for Norwegian Exchange Rate Forecasting. Master's Thesis 2016, Norwegian University of Life Sciences, School of Economics and Business.

Akram, Q. Farooq (2003). When does the oil price affect the Norwegian exchange rate? Working Paper 8/2000, Norges Bank 2000.

Akram, Q. Farooq (2002). PPP in the medium run despite oil shocks: The case of Norway. Working Paper 4/2002. Norges Bank 2002.

Bernhardsen, T. og Ø. Røisland (2000). Hvilke faktorer påvirker kronekursen? Penger og Kreditt 3/00, s. 187-194. Norges Bank 2000.

Bjørnland, H. C. and H. Hungnes (2003). Fundamental determinants of the long run real exchange rate: The case of Norway. Discussion Papers No. 326, August 2002. Statistisk Sentralbyrå, Forskningsavdelingen.

Bjørnland, H. C. og H. Hungnes (2006). The Importance of Interest Rates for Forecasting the Exchange Rate. Journal of Forecasting, 25, 209-221. Journal of forecasting 25 (3): 209 -221). 
Bjørnstad, R. og E. S. Jansen (2006). Renta bestemmer det meste. SSB Økonomiske Analyser 6/2006.

Bjørnstad, R. og E. S. Jansen (2007). The NOK/euro exchange rate after inflation targeting: The interest rate rules. Discussion Papers No. 501, May 2007. Statistisk Sentralbyrå, (2007).

Blanchard, O. (2000). What do we know about Macroeconomics that Fisher and Wicksell did not? Quarterly Journal of Economics, 2000, v115(4, Nov), 1375-1409.

Dornbusch, R. (1976). Expectation and exchange rate dynamics, Journal of Policy economy 84 (6): 1161 - 1176.

Eitrheim, Ø., E. Frøyland and Ø. Røisland (1999). Can the price of currency options provide an indication of market perceptions of the uncertainty attracted to the krone exchange rate. Economic Bulletin, Vol. Lxx No. 1.

Flatner, Alexander (2009). Norske kroner ingen trygg havn. Aktuell kommentar Nr. 3/09. Norges Bank 2009.

Frankel, A. and A Jeffrey (1979). A Theory of Floating Exchange Rates Based on Real Interest Differential, American Economic Review, 64 (May 1979), pp. 610-622.

Frenkel, A. (1976). Monetary Approach to the Exchange Rate: Doctrinal Aspects and Empirical Evidence, The Scandinavian Journal of Economics Vol. 78, No. 2, Proceedings of a Conference on Flexible Exchange Rates and Stabilization Policy (Jun., 1976), pp. 200-224.

Gimmingsrud, A. (2012). Sammenhengen mellom valutakurs og prisen på råolje. Masteroppgave i samfunnsøkonomi, NMBU, 2012.

Kj, A. (2015). Hvilke faktorer bestemmer kronekursen - en empirisk analyse av kronekursen. Masteroppgave i samfunnsøkonom, NHH, 2015

Kloster, A., R. Lokshall and Ø. Røisland (2003). Hvor mye av bevegelsene i kronekursen kan forklares av rentedifferansen? Kapittel 6, Norges Banks skriftserie nr. 31. Hvilke faktorer kan forklare utviklingen i valutakursen? Øyvind Eitrheim og Kristin Guldbrandsen (red.). Oslo 2003.

Meese, Richard A. and Kenneth Rogoff (1983). Empirical exchange rate models of the seventies: Do they fit out of sample? Journal of International Economics 1983, s. 3-24.

Naug, B. E. (2004). Faktorer bak utviklingen i kronekursen - en empirisk analyse. Kapittel 7, Norges Banks skriftserie nr. 31. Hvilke faktorer kan forklare utviklingen i valutakursen? Øyvind Eitrheim og Kristin Guldbrandsen (red.). Oslo 2003. NA24 (2009).

Papadamou, S. and T. Markopoulos (1012). The monetary approach to the exchange rate determination for a "petroccurrency". The case of Norwegian krone. International Advances in Economic Research 18(3): 299 -314. Springer.

Rime, D. and E. Sojli (2006). Ordreanalyse av valutakurser, Penge og Kreditt 2 /2006, side 110-115, Norges Bank, 2006.

Reinton, H. and S. Ongene (1999). Out-of-sample forecasting performance of single equation monetary exchange rate models in Norwegian currency markets, Applied Financial Economics, 9, 545-550. 


\section{Sample:}

\section{APPENDIX 1: DIAGNOSTIC PROPERTIES}

2001-2016, monthly observations

Number of observations: 186

Mean (log exchange rate) $-0,00029$

$R^{2}=0,23$

Log-likelihood $=\mathbf{4 9 5 . 8 1 4}$

\section{Asympotic test:}

Che 2(2) $=58.170$

Skewwness: 1,0455

Excess Kurtosis: 2,04122

\section{Normality test,}

Jarque-Bera Test - observatory 21,5

Tesr-criterion $>13,2$

Arch 1-1 test:

$\mathrm{F}(1,121)=0,12730$

\section{Stationarity test:}

Augmented-Dickey-Fuller test: All variables on growth form were stationary. Variable on level form are not stationary. indicate co-integration. In this case, we can make use of level variable in misalignment model.

\section{Autokorrelation test:}

Durban Watson test: 1,95

Test-criterion $>1,437$

\section{Heteroscedasticity test:}

White's test. Test - observatory: 15,9

Test-criterion $>13,2$

\section{Multicollinearities tests:}

The table below exhibits the structure of the correlation matrix.

Table Appendix: The number in groups with varying degree of correlation

\begin{tabular}{|l|l|l|l|}
\hline Less than 0,20 & $0,20-0,30$ & $0.30-0,50$ & Higher than 0,50 \\
\hline 68 & 6 & 4 & 0 \\
\hline
\end{tabular}

